This is an author produced version of a paper published in SCANDINAVIAN JOURNAL OF FOREST RESEARCH. This paper has been peer-reviewed but does not include the final publisher proofcorrections or journal pagination.

Citation for the published paper:

Lidestav, Gun and Ekström, Magnus. (2000). Introducing Gender in Studies on Management Behaviour Among Non-industrial Private Forest Owners. Scandinavian Journal of Forest Research. 15: 3, 378-386. ISSN 0282-7581 http://dx.doi.org/ 10.1080/028275800448011

Access to the published version may require journal subscription. Published with permission from: Taylor \& Francis

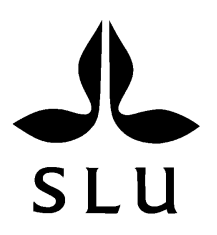




\title{
Introducing Gender in Studies on Management Behaviour Among Non-industrial Private Forest Owners
}

\author{
GUN LIDESTAV ${ }^{1}$ and MAGNUS EKSTRÖM ${ }^{2}$ \\ ${ }^{1}$ Department of Silviculture and ${ }^{2}$ Department of Forest Resource Management and Geomatics, Swedish University of \\ Agricultural Science, S-901 83 Umeå, Sweden
}

\begin{abstract}
Lidestav, G. and Ekström, M. $\left({ }^{1}\right.$ Department of Silviculture and ${ }^{2}$ Department of Forest Resource Management and Geomatics, Swedish University of Agricultural Science, S-901 83 Umeå, Sweden). Introducing gender in studies on management behaviour among non-industrial private forest owners. Received August 14, 1998. Accepted November 16, 1999. Scand. J. For. Res. 15: 378-386, 2000.

The genderization of non-industrial private forest (NIPF) ownership creates different conditions for male and female forest owners. To compare male and female forest management behaviour and to examine whether observed differences should be understood in terms of gender, data from the Swedish National Board of Forestry's interview inquiry were used. Differences in frequency of harvesting and silvicultural operations were examined by binary logistic regression and differences in harvesting volume were tested by a multiple regression analysis. In all analyses sex of the owner was introduced as one of the explanatory variables. The sex of the owner was found to have a significant effect on the frequency of harvesting, cleaning and supplementary planting, but not on planting and mechanized scarification. In the cases when the sex of the owner was a significant factor, the degree of activity among the female owners was found to be lower. Results regarding harvested volumes did not expose any significant differences in harvesting management strategies between male and female owners. Key words: forestry activity, gender, management behaviour, non-industrial private forest owners.
\end{abstract}

\section{INTRODUCTION}

In Western countries, gender equality, in terms of equal rights for women and men, is today considered as an important public goal. A social order built on male dominance and segregation of sexes is questioned while integration of the sexes in all areas of society has become an expressed ideal. In the process of social changes towards gender equality, the Scandinavian countries have, in several areas, been in the frontline.

The concept of "gender" was introduced in 1960s and 1970s to define cultural and social aspects of sex (Stoller 1968, Rubin 1975). Since then there has been an ongoing discussion, especially within feminism, about this distinction and the use and definition of sex and gender, respectively. In this study of male and female non-industrial private forestry (NIPF) owners' management behaviour, sex refers to features that can be directly observed, e.g. in registers, while gender refers to structures and patterns embedded in a social and cultural context of NIPF ownership.

Within farm forestry or NIPF, where a patrilinear inheritance tradition of transferring property down through the generations has prevailed, there have been considerable recent changes. In Norway, an amendment to the Act of Succession to Farm Proper- ties, passed in 1974, gives women equal rights to inherit farms. Consequently, the share of female NIPF owners has increased and amounted to $15 \%$ of all owners in 1989 (Strupstad 1993). In Finland female forest owners have raised their share from 17\% in 1975 to $28 \%$ in 1990 (Ripatti \& Järveläinen 1997) and in Sweden from 20\% in 1976 to $34 \%$ in 1992 (Lidestav 1998a). As these changes reflect a general social change towards equal rights, it is likely that similar development is in progress or can be forecast in other Western countries with a large NIPF ownership.

NIPF owners not only transfer their forest land to their children and grandchildren, they also transfer expectations, knowledge and role models. According to Törnqvist (1995 p. 398), "the forest estate constitutes a social space which links several generations in different types of commonality: shared values, living and work conditions and shared means of support". However, there is a gendered structured division of work on family farms (Whatmore 1991) and within farm forestry (Johansson 1989, Strupstad 1993) which constitutes barriers for women's participation in forestry management (Brandth \& Haugen 1998). Forestry knowledge is less often transferred from fathers to daughters than from fathers to sons and 
very seldom from mothers to children of either sex (Lidestav 1998b). Compared with male forest owners, female forest owners attend fewer forestry education and training courses or local extension activities. They also consider their own knowledge in forestry management considerably lower (Lidestav 1998b). Speaking about forestry work, the cultural gendering is so strong that "women become quite out of the place" (Brandth \& Haugen 1998 p. 439). Female forest owners' participation in practical forestry work is less common than male owners', especially regarding harvesting (Strupstad 1993, Lidestav 1998b). At present, these conditions are essential parts of the construction of femininity and masculinity within NIPF ownership. This genderization of NIPF ownership is likely to have an impact on forestry management behaviour. The ways in which it appears or is expressed are, however, unclear.

Differences in forest management behaviour can, as with other observed differences between women and men, be interpreted quite differently depending on theoretical foundation. According to "equal rights" feminism, one of the two contrasting theoretical foundations, men and women are essentially similar (Harding 1986, Johnson 1988). Differences between men and women are attributed to social causes, created in the context of oppression in the public and private spheres. If barriers and oppression are removed, differences will disappear. Research with this position has focused to a large extent on making women's work and contribution visible and identifying barriers for women's participation (Gasson 1992). Legislation and public policies aiming at gender equality derive mainly from this tradition. The other position, "standpoint" feminism or the womancentred perspective (Harding 1986, Johnson 1988), stresses difference and claims that men and women have different value orientations. Owing to the division of work between the sexes, which gives men and women different experiences, they develop different rationalities. As women are socialized to be responsible for the caring functions within society (Prokop 1981) they develop what Sørensen (1982) calls a rationality of responsibility, while men's rationality is technically-economically orientated. By studying how girls and boys with rights to the succession to the family farm deal with the question of taking over, Haugen (1994 p. 98) gives an illustrative example of this difference. She found that for girls it is a question of "an evaluation of many conditions in which other people's interests play an important part, boys evalu- ate the situation accordingly to their own personal interests". In this context, an interesting question at issue is whether gender has an effect on harvesting and silvicultural activities. From the similarity approach one might expect no differences in harvesting and silvicultural activity on NIPF holdings owned by woman or men attributed to gender. From the focus on difference one might expect that female owners, compared with male owners, have a higher extent of regeneration measurements in relation to final felling. In accordance with the woman-centred perspective (Merchant 1980, Shiva 1989) one might expect that male and female owners practise different harvesting strategies, e.g. that female owners prefer to extract a higher part of the total timber production volume in thinning.

Only a small number of studies has approached the question of differences in male and female forest owners' management behaviour and even fewer have researched how observed differences or similarities should be understood in terms of gender. Recent Finnish research (Ripatti 1998) shows that timber sales were significantly lower among female owners than among male owners. Ripatti also found differences in background features such as owner's age and place of residence, size and main use of the holding, type of ownership and participation in forestry extension, which according to the author explain the difference in timber-sales behaviour. Regarding timber-sale probability, female owners were more sensitive to changes in stumpage price and participation in training courses. Apart from sensitivity to price, it seems that Ripatti's results are in line with equal rights feminism. Even Strupstad (1990) is of the impression that difference in harvesting activities between male- and female-owned holdings is related to the size of the property, as well as civil status. A possible expression for gender differences in value orientation is, however, her interpretation of the findings that women value regeneration work more highly than do men. A lower activity level on holdings with female owners has also been reported from Sweden by Anon. (1981), Sennblad (1996) and Lidestav (1998a). In the latter study, no significant differences were found between male and female forest owners regarding age of the owner, size of the holdings or number of owners of the holding. However, there is a problem of representation in these Swedish studies. When the ownership structure that appears in these studies is compared with data from the Census of Agriculture (Anon. 1979, 1994), it is 
evident that female joint owners are represented by a respondent from the other sex to a much larger extent than are male joint owners. Consequently, none of the Swedish studies has satisfactorily examined the occurrence and any possible influence of a gender factor.

The aim of the present study was to compare forestry management behaviour between male- and female-owned holdings and to determine whether observed differences between the sexes are associated with differences in ownership structure only, or whether gender should be introduced as an explanatory variable in studies of management behaviour.

\section{MATERIALS AND METHODS}

The analysis of forest activities is based on data from The National Board of Forestry's interview inquiry regarding cuttings and silviculture in small-scale forestry from 1992, 1993 and 1994. The inquiry methodology, as well as results for the complete population of NIPF owners, are presented in the Statistical Yearbook of Forestry (Anon. 1995). The original sample was stratified by county (no. 24) and acreage. The area classes were 5-24 ha, 25-49 ha, 50-99 ha, 100-199 ha, 200-399 ha, 400-999 ha and 1000-4999 ha, respectively. In total, the sample consisted of 6717 non-industrial forest holdings with a minimum size of 5.0 ha (Table 1). The response rate was $93 \%$ each year. The problem of female joint owners represented by male respondents, mentioned above, was avoided by concentrating the study on holdings owned by one owner. To identify male and female single owners, complementary information regarding the number of owners on each holding and the respondent's (owner or one of the owners) age and sex were obtained from Statistics Sweden. Holdings owned by organizations, corporations, the public or by more than one owner were excluded, and the material then consisted of 3156 holdings owned by
2565 male and 595 female owners (respondents). The reported activity from each of these holdings refers to one year and the mean values presented should be seen as an annual value from 1992 to 1994.

To examine whether male and female owners practise different harvesting strategies, harvesting volumes in final felling, in thinnings and in total were analysed for those who had reported harvesting that year. The data were analysed by multiple regression (Draper \& Smith 1998). Variables to be explained were: (i) volume in final felling; (ii) volume in final felling per ha; (iii) volume in thinning; (iv) volume in thinning per ha; (v) total harvested volume; and (vi) total harvested volume per ha. Explanatory variables used in the model were: (a) sex of the owner (male $=0$ and female =1); (b) age of the owner (yrs): in accordance with the lifecycle hypothesis (compare Kuuluvainen 1989, Lönnstedt 1997), increasing age of the owner has been found to reduce the frequency of harvesting activity; (c) ownership size (ha): Scandinavian as well as American studies on NIPF owners' attitudes and behaviour have indicated ownership size to be an important explanatory variable (Thomson \& Jones 1981, Straka et al. 1984, Lönnstedt 1989, Kuuluvainen 1989, Carlén 1990, Cleaves \& Bennet 1995); and (d) mean site quality $\left(\mathrm{m}^{3} \mathrm{ha}^{-1} \mathrm{yr}^{-1}\right)$ : mean site quality for the county was introduced to the model as growing conditions vary between northern and southern Sweden (Anon. 1995).

For the purpose of regression analyses, logarithmic transformations (with base 10) of the variables were found to be most suitable. So, when referring to the response variables (i)-(vi) and the explanatory variables (b)-(d) in the text, it is actually the logarithmically transformed values that are used in the models. The use of the logarithmic transformation stabilized the variance of the response, and at the same time linearized the relationship between the mean value of the response variable and the explanatory variables. Furthermore, these transformations resulted in a Gaussian error distribution.

Table 1. NIPF interview inquiry, total number of holdings $(N)$, sample and respondents

\begin{tabular}{llllll}
\hline & & & & \multicolumn{2}{l}{ Holdings owned by: } \\
\cline { 5 - 6 } Year & $N$ & Sample & Respondents & 1 male owner & 1 female owner \\
\hline 1992 & 206882 & 2236 & 2087 & 892 & 187 \\
1993 & 203551 & 2232 & 2070 & 865 & 201 \\
1994 & 203549 & 2249 & 2093 & 808 & 207 \\
$1992-1994$ & 204661 & 6717 & 6250 & 2565 & 595 \\
\hline
\end{tabular}


In these analyses, there is some remaining heteroscedascity, which was expected since the collected data were stratified (with respect to area and county). One can fall back on a weighted analysis to try to correct for remaining heteroscedascity in a transformed response; but such ad hoc approaches are not always satisfactory. There are limits as to how far one can adapt the standard framework to accommodate different types of data. Therefore, multiple regression analyses were performed both with and without weights. It turned out that the analyses with and without weights gave almost identical results, with one exception (see below).

To examine whether harvesting and silvicultural activity is affected by gender, or whether other explanatory variables are simply differently distributed between male and female owners, binary logistic regression (Hosmer \& Lemeshow 1989) was used. The variable to be explained is dichotomous, e.g. equal to 1 if a certain activity has taken place during the year, and equal to 0 if not. The explanatory variables were the same as used in the multiple regression above. The use of the log-transformation of the variables (b)-(d) was chosen after graphical studies, where the explanatory variables were grouped and scatterplots made of the empirical logit transform against each of the explanatory variables. Since the weighted analyses in the multiple regression studies above differed only slightly from the non-weighted ones (with one exception), the stratification of the data was not taken into account when the logistic regression was performed.

Throughout the paper the level of significance is set at $5 \%$.

\section{RESULTS}

The total number of single NIPF owners was estimated to be 115600 people, of whom $21.4 \%$ were female owners. In this owner category the women owned $18.5 \%$ of the forest land while men owned $81.5 \%$. This implies a larger mean size of male-owned holdings, 51.9 ha compared with 43.3 ha, which was found to be a significant difference. The distribution of area classes within the sample revealed a higher representation of female ownership on the smallest holdings (Table 2). Furthermore, the mean age of female owners was 2.5 yrs higher than the mean age of male owners (58.3 yrs and $55.8 \mathrm{yrs}$, respectively) and female owners were, compared with male owners, typically skewed towards older age groups (Table $3)$.
Table 2. Area class distribution among male and female single NIPF owners in Sweden (\%)

\begin{tabular}{lrc}
\hline Forest area (ha) & Men & Women \\
\hline $5-24$ & 16 & 21 \\
$25-49$ & 21 & 21 \\
$50-99$ & 23 & 23 \\
$100-199$ & 20 & 17 \\
$200-399$ & 10 & 11 \\
$400-999$ & 7 & 7 \\
$1000-4999$ & 3 & 1 \\
Total & 100 & 100 \\
\hline
\end{tabular}

Male owners reported a higher occurrence of forestry activity during $1 \mathrm{yr}$ than did female owners (Table 4). When testing the differences associated with the owner's sex, age, holding size or mean site quality, the entire study material was used as a basis. The estimated logit model showed that female forest owners were less inclined to carry out final felling, thinning and other cuttings (Table 5). Note that in both Tables 5 and 6 the results for the "full model" are presented, and if some parameters were not significantly different from zero, a (final) reduced model is also presented.

Irrespective of sex, older owners were less likely to carry out harvesting activities, while larger ownership and higher site quality increased the frequency of harvesting. Cleaning was more frequent among male forest owners and on holdings of larger size and with higher site quality. The age of the owner had no significant impact on cleaning activity. Regarding mechanized scarification and planting, no significant influence of the owner's sex was found, while age had a negative impact. Larger ownerships and higher site quality were correlated with a higher frequency of mechanized scarification and planting. Female own-

Table 3. Age distribution among male and female single NIPF owners in Sweden (\%)

\begin{tabular}{lrc}
\hline Age (yrs) & Men & Women \\
\hline $0-29$ & 3 & 4 \\
$30-39$ & 14 & 9 \\
$40-49$ & 25 & 20 \\
$50-59$ & 23 & 28 \\
$60-69$ & 18 & 18 \\
$70-79$ & 11 & 14 \\
$\geq 80$ & 5 & 8 \\
Total & 100 & 100 \\
\hline
\end{tabular}


Table 4. Forestry activity on NIPF holdings by the owner's sex (\% of NIPF holdings)

\begin{tabular}{lrrrrrr}
\hline & \multicolumn{2}{c}{ Males } & & & \multicolumn{2}{l}{ Females } \\
\cline { 2 - 3 } \cline { 5 - 6 } Forestry activity & MV & SE & & MV & SE \\
\hline Final felling & 16.7 & 0.9 & & 12.1 & 1.9 \\
Thinning & 32.9 & 1.3 & & 20.8 & 2.0 \\
Other cuttings & 44.5 & 1.4 & & 36.2 & 2.7 \\
Mechanized scarification & 5.5 & 0.5 & & 4.5 & 1.0 \\
Planting & 12.3 & 0.8 & & 10.7 & 1.4 \\
Supplementary planting & 9.2 & 0.8 & 4.9 & 1.3 \\
Cleaning & 30.2 & 1.3 & & 21.2 & 2.4 \\
Any activity & & 75.3 & 1.3 & & 59.2 & 2.8 \\
\hline
\end{tabular}

MV: mean value; SE: standard error.

${ }^{a}$ Any of the above-mentioned activities including pruning.

ers and older owners were less inclined to do supplementary planting, while these activities were more frequent on holdings of larger size and with higher site quality.

On those properties where harvesting had taken place, differences in harvesting volume were examined by multiple regression. Results of the nonweighted analyses showed that harvested volume in final felling and in total increased with size of the holding and site quality, while harvested volume per ha in final felling increased with increasing site quality only (Table 6). Total harvested volume per ha, however, increased with both the size of the holding and site quality. Harvested volume in thinning increased with increasing size of the holding, site quality and age of the owner. Thinning volume per ha increased with size of the holding and site quality only. In no case did the owner's sex have any significant influence on harvested volume. When weighted multiple regression calculations were performed, the results obtained differed only slightly from the nonweighted ones, with one exception: in the weighted analysis, total harvested volume per ha increased with site quality only. Therefore, there are some doubts about whether total harvested volume per ha increased with size of the holding or not.

In both logistic regression and multiple regression the inference is justified under certain model assumptions. The adequacy of these models was checked by the use of residuals and other similar statistics designed to detect anomalous observations or unexpected patterns, and by overall test statistics of goodness of fit. Besides problems related to how to take the stratification of data into account, these examinations substantiated the adequacy of the presented models.

\section{DISCUSSION}

The results presented in this study are based on high-quality data as the respondent rate was very high and as the answers were given with assistance of the county ranger. Furthermore, the results refer to actions and situations from 3 successive years compiled into a "mean year". There is also good correspondence between the estimated proportion of female owners among single NIPF owners found in this study and that found by Anon. (1994). In both studies, the proportions were set to $21 \%$ female owners and $79 \%$ male owners. Furthermore, a lower mean size of forest holdings and a higher age among female single NIPF owners than among male owners has also been reported by Lidestav (1997) and in Finland by Ripatti (1998). In the USA Effland et al. (1993) report that female farmers' holdings are onethird smaller than male farmers' holdings. While a higher mean age among female single NIPF owners might be explained by a higher life expectancy for women in Western countries (biological sex), the significantly lower mean size of female owned holdings seems to be part of a gendered social and cultural context of NIPF ownership.

Forestry activity on a holding depends on the owner, natural conditions reflected by the site quality class and the present state of the forest. A lower activity in, for example, harvesting does not necessarily imply a lower harvesting intensity, defined as performed cuttings in relation to possible cuttings. For example, it should be noted that harvesting and silvicultural activities are, in general, less frequent in northern Sweden than in southern Sweden, as the mean site quality in northern Sweden (five northernmost counties) is only half the mean site quality in southern Sweden (Anon. 1995). There are also considerable differences in mean site quality between holdings within each county, but the material used in this study contains no information of the mean site quality on the individual holding. Neither does the material give information about standing volume and age class distribution on the holdings, although the comparison of harvesting and silvicultural activities presupposes that these conditions are similar on male and female owned holdings.

In this study, as in the Finnish study by Ripatti (1998), harvesting activity was found to be less fre- 
Table 5. Harvesting and silvicultural activity: logistic regression table

\begin{tabular}{|c|c|c|c|c|}
\hline Predictor & Coefficient & $\mathrm{SD}$ & $p$-value & Odds ratio \\
\hline \multicolumn{5}{|c|}{ Final felling (no activity $=0$, activity $=1$ ) } \\
\hline $\begin{array}{l}\text { Constant } \\
\operatorname{Sex}(M=0, F=1) \\
\log (\text { area }) \\
\log (\text { age }) \\
\text { Log(mean site quality })\end{array}$ & $\begin{array}{r}-3.747 \\
-0.399 \\
1.761 \\
-1.477 \\
2.515\end{array}$ & $\begin{array}{l}0.675 \\
0.122 \\
0.096 \\
0.346 \\
0.244\end{array}$ & $\begin{array}{l}0.000 \\
0.001 \\
0.000 \\
0.000 \\
0.000\end{array}$ & $\begin{array}{r}0.67 \\
5.88 \\
0.23 \\
12.50\end{array}$ \\
\hline \multicolumn{5}{|c|}{ Thinning $($ no activity $=0$, activity $=1$ ) } \\
\hline $\begin{array}{l}\text { Constant } \\
\text { Sex }(M=0, F=1) \\
\log (\text { area }) \\
\log (\text { age }) \\
\log (\text { mean site quality })\end{array}$ & $\begin{array}{r}-2.210 \\
-0.510 \\
0.977 \\
-1.242 \\
2.793\end{array}$ & $\begin{array}{l}0.598 \\
0.106 \\
0.079 \\
0.309 \\
0.216\end{array}$ & $\begin{array}{l}0.000 \\
0.000 \\
0.000 \\
0.000 \\
0.000\end{array}$ & $\begin{array}{r}0.60 \\
2.63 \\
0.29 \\
16.67\end{array}$ \\
\hline \multicolumn{5}{|c|}{ Other cuttings (no activity $=0$, activity $=1$ ) } \\
\hline $\begin{array}{l}\text { Constant } \\
\text { Sex }(M=0, F=1) \\
\log (\text { area }) \\
\log (\text { age }) \\
\log (\text { mean site quality })\end{array}$ & $\begin{array}{r}-0.688 \\
-0.422 \\
0.568 \\
-0.942 \\
1.638\end{array}$ & $\begin{array}{l}0.566 \\
0.096 \\
0.071 \\
0.293 \\
0.198\end{array}$ & $\begin{array}{l}0.224 \\
0.000 \\
0.000 \\
0.001 \\
0.000\end{array}$ & $\begin{array}{l}0.65 \\
1.75 \\
0.39 \\
5.26\end{array}$ \\
\hline \multicolumn{5}{|c|}{ Mechanized scarification (no activity $=0$, activity $=1$ ) } \\
\hline $\begin{array}{l}\text { Constant } \\
\operatorname{Sex}(M=0, F=1) \\
\log (\text { area }) \\
\log (\text { age }) \\
\log (\text { mean site quality })\end{array}$ & $\begin{array}{r}-3.722 \\
-0.204 \\
2.040 \\
-2.005 \\
1.238\end{array}$ & $\begin{array}{l}0.874 \\
0.168 \\
0.124 \\
0.463 \\
0.315\end{array}$ & $\begin{array}{l}0.000 \\
0.223 \\
0.000 \\
0.000 \\
0.000\end{array}$ & $\begin{array}{l}0.81 \\
7.69 \\
0.13 \\
3.45\end{array}$ \\
\hline $\begin{array}{l}\text { Constant } \\
\log (\text { area }) \\
\log (\text { age }) \\
\text { Log(mean site quality })\end{array}$ & $\begin{array}{r}-3.726 \\
2.046 \\
-2.036 \\
1.253\end{array}$ & $\begin{array}{l}0.873 \\
0.124 \\
0.462 \\
0.315\end{array}$ & $\begin{array}{l}0.000 \\
0.000 \\
0.000 \\
0.000\end{array}$ & $\begin{array}{l}7.69 \\
0.13 \\
3.45\end{array}$ \\
\hline \multicolumn{5}{|c|}{ Planting (no activity $=0$, activity $=1$ ) } \\
\hline $\begin{array}{l}\text { Constant } \\
\text { Sex }(M=0, F=1) \\
\log (\text { area }) \\
\text { Log(age }) \\
\text { Log(mean site quality })\end{array}$ & $\begin{array}{r}-4.089 \\
-0.177 \\
1.548 \\
-1.341 \\
2.526\end{array}$ & $\begin{array}{l}0.729 \\
0.132 \\
0.099 \\
0.377 \\
0.266\end{array}$ & $\begin{array}{l}0.000 \\
0.180 \\
0.000 \\
0.000 \\
0.000\end{array}$ & $\begin{array}{r}0.84 \\
4.76 \\
0.26 \\
12.50\end{array}$ \\
\hline $\begin{array}{l}\text { Constant } \\
\log (\text { area }) \\
\text { Log(age) } \\
\text { Log(mean site quality) }\end{array}$ & $\begin{array}{r}-4.086 \\
1.553 \\
-1.372 \\
2.540\end{array}$ & $\begin{array}{l}0.729 \\
0.099 \\
0.376 \\
0.266\end{array}$ & $\begin{array}{l}0.000 \\
0.000 \\
0.000 \\
0.000\end{array}$ & $\begin{array}{r}4.76 \\
0.25 \\
12.50\end{array}$ \\
\hline \multicolumn{5}{|c|}{ Supplementary planting (no activity $=0$, activity $=1$ ) } \\
\hline $\begin{array}{l}\text { Constant } \\
\operatorname{Sex}(M=0, F=1) \\
\log (\text { area }) \\
\text { Log(age }) \\
\text { Log(mean site quality })\end{array}$ & $\begin{array}{r}-5.026 \\
-0.573 \\
1.330 \\
-1.209 \\
3.282\end{array}$ & $\begin{array}{l}0.862 \\
0.177 \\
0.110 \\
0.445 \\
0.328\end{array}$ & $\begin{array}{l}0.000 \\
0.001 \\
0.000 \\
0.007 \\
0.000\end{array}$ & $\begin{array}{r}0.56 \\
3.85 \\
0.30 \\
25.00\end{array}$ \\
\hline \multicolumn{5}{|c|}{ Cleaning (no activity $=0$, activity $=1$ ) } \\
\hline $\begin{array}{l}\text { Constant } \\
\operatorname{Sex}(M=0, F=1) \\
\log (\text { area }) \\
\log (\text { age }) \\
\log (\text { mean site quality })\end{array}$ & $\begin{array}{r}-3.439 \\
-0.359 \\
1.037 \\
-0.351 \\
2.101\end{array}$ & $\begin{array}{l}0.603 \\
0.104 \\
0.079 \\
0.309 \\
0.212\end{array}$ & $\begin{array}{l}0.000 \\
0.001 \\
0.000 \\
0.256 \\
0.000\end{array}$ & $\begin{array}{l}0.70 \\
2.86 \\
0.70 \\
8.33\end{array}$ \\
\hline $\begin{array}{l}\text { Constant } \\
\text { Sex }(M=0, F=1) \\
\log (\text { area }) \\
\log (\text { mean site quality })\end{array}$ & $\begin{array}{r}-4.067 \\
-0.367 \\
1.048 \\
2.111\end{array}$ & $\begin{array}{l}0.246 \\
0.104 \\
0.078 \\
0.212\end{array}$ & $\begin{array}{l}0.000 \\
0.000 \\
0.000 \\
0.000\end{array}$ & $\begin{array}{l}0.69 \\
2.86 \\
8.33\end{array}$ \\
\hline
\end{tabular}


Table 6. Harvesting volume: multiple regression table

\begin{tabular}{|c|c|c|c|}
\hline Predictor & Coefficient & $\mathrm{SD}$ & $p$-value \\
\hline \multicolumn{4}{|c|}{$\log ($ harvested volume in final felling) } \\
\hline $\begin{array}{l}\text { Constant } \\
\operatorname{Sex}(M=0, F=1) \\
\log (\text { area }) \\
\log (\text { age }) \\
\log (\text { mean site quality })\end{array}$ & $\begin{array}{l}0.913 \\
0.084 \\
0.626 \\
0.068 \\
0.312\end{array}$ & $\begin{array}{l}0.234 \\
0.045 \\
0.030 \\
0.121 \\
0.087\end{array}$ & $\begin{array}{l}0.000 \\
0.064 \\
0.000 \\
0.574 \\
0.000\end{array}$ \\
\hline $\begin{array}{l}\text { Constant } \\
\log (\text { area }) \\
\text { Log(mean site quality })\end{array}$ & $\begin{array}{l}1.124 \\
0.622 \\
0.320\end{array}$ & $\begin{array}{l}0.097 \\
0.030 \\
0.087\end{array}$ & $\begin{array}{l}0.000 \\
0.000 \\
0.000\end{array}$ \\
\hline \multicolumn{4}{|c|}{$\log ($ harvested volume per hectare in final felling) } \\
\hline $\begin{array}{l}\text { Constant } \\
\text { Sex }(M=0, F=1) \\
\text { Log(area) } \\
\text { Log(age }) \\
\text { Log(mean site quality })\end{array}$ & $\begin{array}{r}1.937 \\
-0.017 \\
0.007 \\
-0.015 \\
0.505\end{array}$ & $\begin{array}{l}0.093 \\
0.018 \\
0.012 \\
0.048 \\
0.034\end{array}$ & $\begin{array}{l}0.000 \\
0.335 \\
0.568 \\
0.761 \\
0.000\end{array}$ \\
\hline $\begin{array}{l}\text { Constant } \\
\text { Log(mean site quality) }\end{array}$ & $\begin{array}{l}1.910 \\
0.503\end{array}$ & $\begin{array}{l}0.028 \\
0.034\end{array}$ & $\begin{array}{l}0.000 \\
0.000\end{array}$ \\
\hline $\begin{array}{l}\text { Log(harvested volume ir } \\
\text { Constant } \\
\text { Sex }(M=0, F=1) \\
\log (\text { area }) \\
\log (\text { age }) \\
\text { Log(mean site quality) }\end{array}$ & $\begin{array}{r}-0.692 \\
0.018 \\
0.781 \\
0.265 \\
0.894\end{array}$ & $\begin{array}{l}0.197 \\
0.038 \\
0.025 \\
0.102 \\
0.069\end{array}$ & $\begin{array}{l}0.000 \\
0.638 \\
0.000 \\
0.010 \\
0.000\end{array}$ \\
\hline $\begin{array}{l}\text { Constant } \\
\log (\text { area }) \\
\log (\text { age }) \\
\text { Log(mean site quality) }\end{array}$ & $\begin{array}{r}-0.674 \\
0.780 \\
0.267 \\
0.894\end{array}$ & $\begin{array}{l}0.194 \\
0.025 \\
0.102 \\
0.069\end{array}$ & $\begin{array}{l}0.001 \\
0.000 \\
0.009 \\
0.000\end{array}$ \\
\hline $\begin{array}{l}\text { Log(harvested volume } p \\
\text { Constant } \\
\text { Sex }(M=0, F=1) \\
\log (\text { area }) \\
\log (\text { age }) \\
\text { Log(mean site quality) }\end{array}$ & $\begin{array}{r}1.310 \\
0.005 \\
0.065 \\
-0.012 \\
0.235\end{array}$ & $\begin{array}{l}0.092 \\
0.017 \\
0.011 \\
0.047 \\
0.032\end{array}$ & $\begin{array}{l}0.000 \\
0.788 \\
0.000 \\
0.793 \\
0.000\end{array}$ \\
\hline $\begin{array}{l}\text { Constant } \\
\log (\text { area }) \\
\log (\text { mean site quality })\end{array}$ & $\begin{array}{l}1.293 \\
0.065 \\
0.235\end{array}$ & $\begin{array}{l}0.035 \\
0.011 \\
0.032\end{array}$ & $\begin{array}{l}0.000 \\
0.000 \\
0.000\end{array}$ \\
\hline \multicolumn{4}{|c|}{ Log(total harvested volume) } \\
\hline $\begin{array}{l}\text { Constant } \\
\operatorname{Sex}(M=0, F=1) \\
\log (\text { area }) \\
\log (\text { age }) \\
\log (\text { mean site quality })\end{array}$ & $\begin{array}{r}-0.331 \\
-0.032 \\
0.929 \\
-0.089 \\
1.148\end{array}$ & $\begin{array}{l}0.196 \\
0.035 \\
0.025 \\
0.100 \\
0.068\end{array}$ & $\begin{array}{l}0.091 \\
0.364 \\
0.000 \\
0.374 \\
0.000\end{array}$ \\
\hline $\begin{array}{l}\text { Constant } \\
\log (\text { area }) \\
\text { Log(mean site quality })\end{array}$ & $\begin{array}{r}-0.528 \\
0.932 \\
1.151\end{array}$ & $\begin{array}{l}0.076 \\
0.024 \\
0.068\end{array}$ & $\begin{array}{l}0.000 \\
0.000 \\
0.000\end{array}$ \\
\hline \multicolumn{4}{|c|}{$\log ($ total harvested volume per hectare) } \\
\hline $\begin{array}{l}\text { Constant } \\
\text { Sex }(M=0, F=1) \\
\log (\text { area }) \\
\log (\text { age }) \\
\log (\text { mean site quality })\end{array}$ & $\begin{array}{r}-0.331 \\
-0.032 \\
-0.071 \\
-0.089 \\
1.148\end{array}$ & $\begin{array}{l}0.196 \\
0.035 \\
0.025 \\
0.100 \\
0.068\end{array}$ & $\begin{array}{l}0.091 \\
0.364 \\
0.004 \\
0.374 \\
0.000\end{array}$ \\
\hline $\begin{array}{l}\text { Constant } \\
\log (\text { area }) \\
\log (\text { mean site quality })\end{array}$ & $\begin{array}{r}-0.528 \\
-0.068 \\
1.151\end{array}$ & $\begin{array}{l}0.076 \\
0.024 \\
0.068\end{array}$ & $\begin{array}{l}0.000 \\
0.006 \\
0.000\end{array}$ \\
\hline
\end{tabular}


quent on female-owned holdings than on male-owned holdings. Whether Swedish female owners, like Finnish female owners, are more sensitive to changes in stumpage price and forest training courses than male owners (Ripatti 1998) cannot be judged by this study. However, contrary to Ripatti (1998), the present authors consider that these differences in sensitivity should be seen as an expression of cultural and social aspects of sex (i.e. gender).

Results regarding harvested volumes in final felling, thinnings and other cuttings (in total or per ha) do not expose any significant differences in harvesting management strategies between male and female owners. Considering that there are no significant differences in harvested volume in total or per ha, only in harvesting frequency, it is likely that standing volume will increase more on female-owned holdings than on male-owned holdings.

Final felling implies also that regeneration, by law, has to be done by leaving seed trees (natural regeneration), by sowing or by planting, usually in combination with mechanized scarification. In relation to the rate of final felling, female forest owners carry out mechanized scarification and planting to a higher extent than do male owners (see Table 4). For female owners the ratio between frequencies of planting and final felling is $88 \%$, compared with $74 \%$ for male owners. The ratio between frequencies of mechanized scarification and final felling is $37 \%$ for female owners, compared with $33 \%$ for male owners. Because no significant differences in extracted volume per ha in final felling were found between male and female owners it seems unlikely that male owners practise regeneration by seed trees to a higher extent than female owners. This result may indicate that female forest owners are more inclined to regenerate their holdings in general. A similar indication can be found in a Norwegian study (Strupstad 1990).

In summary, this study confirms the assumption that there are some differences in forestry behaviour between male and female forest owners that cannot be explained by differences in the size of the holding, ownership state (single owners only) or the owner's age. These findings call for the introduction of gender in studies on NIPF owners' management behaviour. However, studies on behaviour have to be supplemented by studies of decision making, attitudes and values to obtain a deeper understanding of how femininity and masculinity are constructed and reconstructed within NIPF ownership.

\section{ACKNOWLEDGMENTS}

This study is part of the research project "Female forest-owners' management tradition - activity, attitudes and decision-making", financed by the Swedish Council for Forestry and Agricultural Research (SJFR). We thank Jan Christoffersson PhD, Clas Fries PhD, Professor Lars Lönnstedt and Mrs Dianne Staal Wästerlund for providing constructive comments on earlier drafts of this manuscript.

\section{REFERENCES}

Anon. 1979. Ownership structure in forestry. National Central Bureau of Statistics, Stockholm, Statistical Reports J. 1979: 14, 95 pp. ISSN 0082-0288. (In Swedish with English summary.)

Anon. 1981. Skogsindustrins virkesförsörjning. Betänkande av virkesförsörjningsutredningen, Swedish Official Reports Series 1981: 81, 308 pp. LiberFörlag, Stockholm. ISBN 91-38-06335-2. (In Swedish.)

Anon. 1994. Ownership structure in forestry. Special study in connection to the 1992 Census of Agriculture. Statistics Sweden, Stockholm, Statistical Reports J. 1994: 13, 109 pp. ISSN 0082-0288. (In Swedish with English summary.)

Anon. 1995. Statistical Yearbook of Forestry 1995. National Board of Forestry, Jönköping, Sweden, 348 pp. ISBN 91-88462-25-0. (In Swedish with English summary.)

Brandth, B. \& Haugen, M. S. 1998. Breaking into a Masculine Discourse. Women and Farm Forestry. Sociologia Ruralis. 38: 427-442.

Carlén, O. 1990. Private nonindustrial forest owners' management behaviour. An economic analysis based on empirical data. Dissertation, Dept of Forest Economics, Swedish Univ. of Agric. Sci., Umeå. Report 92, 104 pp. ISSN 0348-2049.

Cleaves, D. A. \& Bennet, M. 1995. Timber harvesting by nonindustrial private forest landowners in western Oregon. West. J. Appl. For. 10: 66-71.

Draper, N. R. \& Smith, H. 1998. Applied Regression Analysis. 3rd edn, 706 pp. John Wiley \& Sons, New York. ISBN 0-471-17082-28.

Effland, A. B., Rogers, D. M. \& Grim, V. 1993. Women as agricultural landowners: what do we know about them? Vol. 67 (2), pp. 235-261. Agric-Hist. University of California Press, Berkeley, CA. ISSN 0002-1482.

Gasson, R. 1992. Farmers' Wives - Their Contribution to the Farm Business. J. Agric. Econ. 43: 74-87.

Harding, S. 1986. The Science Question in Feminism, 269 pp. Cornell University Press, Ithaca, NY. ISBN 0-80149363-3.

Haugen, M. S. 1994 Rural Women's Status in Family and Property Law: Lessons from Norway. In Whatmore S., Marsden, P. and Lowe P. (eds) Gender and Rurality. Critical perspectives on rural change, pp. 87-101. David Fulton Publisher, London. ISBN 1-85346-252-7. 
Hosmer, D. W. \& Lemeshow, S. 1989. Applied Logistic Regression, 307 pp. John Wiley \& Sons, New York. ISBN 0-471-61553-6.

Johansson, E. 1989. Beautiful men, fine women and good work people: gender and skill in northern Sweden, 1850-1950. Gender \& History 1 (2): 200-212.

Johnson, M. 1988. Strong Mothers, Weak Wives, 347 pp. University of California Press, Los Angeles, CA. ISBN 0-520-06161-6.

Kuuluvainen, J. 1989. Nonindustrial private timber supply and credit rationing. Microeconomic foundations with empirical evidence from the Finnish case. Dept of Forest Economics, Swedish Univ. of Agric. Sci., Umeå. Report 85, 224 pp. ISBN 91-576-3732-6.

Lidestav, G. 1997. Female forest owners and female forest holdings - a structure analysis. Dept of Operational Efficiency, Swedish Univ. of Agric. Sci., Umeå. Research Notes No. 298, p. 23. ISSN 0282-2377. (In Swedish with English summary.)

Lidestav, G. 1998a. Women as non-industrial private forest landowners in Sweden. Scand. J. For. Res. 13: 66-73.

Lidestav, G. 1998b. Women as forest owners and forest farmers in Sweden. In Lidestav, G. \& Wästerlund, D. (eds). Women and Forestry, Proceedings of the NordicBaltic Workshop in Balsjö, Sweden, December 7-9, 1998, pp. 55-63. Nordic Council of Ministers, TemaNord 1999: 571, Copenhagen. ISBN 92-893-03603.

Lönnstedt, L. 1989. Goals and cutting decisions of private small forest owners. Scand. J. For. Res. 4: 259-265.

Lönnstedt, L. 1997. Non-industrial private forest owners' decision process: a qualitative study about goals, time perspective, opportunities and alternatives. Scand. J. For. Res. 12: 302-310.

Merchant, C. 1980. The death of Nature: Women, Ecology and the Scientific Revolution, 348 pp. Harper \& Row, San Francisco, CA. ISBN 0-06-250572-6.

Prokop, U. 1981. Kvinnliga livssammanhang, 233 pp. Raben \& Sjögren, Stockholm. ISBN 91-29-55306-7.

Ripatti, P. 1998. Profile of Finnish female forest owners and their timber sales behaviour. Paper presented at the Biennial Meeting of the Scandinavian Society of Forest Economics, Umeå, Sweden, 15 pp.

Ripatti, P. \& Järveläinen, V.-P. 1997. Forecasting structural changes in non-industrial private forest ownership in
Finland. In Saastamoinen, O. \& Tikka, S. (eds). Proceedings of the Biennial Meeting of the Scandinavian Society of Forest Economics, March 1996, Mekrijärvi, Finland. Scandinavian Forest Economics 36: 215-230. ISSN 0355-032X.

Rubin, G. 1975. The traffic in women: notes on the "political economy" of sex. In Reiter, R. R. (ed.). Towards an Anthropology of Women, pp. 157-210. Monthly Review Press, New York. ISBN 0-85345-372-1.

Sennblad, G. 1996. An analysis of the logging behaviour of non-industrial private forest owners in Sweden. Dept of Operational Efficiency, Swedish Univ. of Agric. Sci., Garpenberg. Research Notes 293, 17 pp. ISSN 02822377. (In Swedish with English summary.)

Shiva, V. 1989. Staying Alive. Women, Ecology and Development, 234 pp. Zed Books, London. ISBN 0-86232823-3.

Sørensen, B. A. 1982. The organizational women and the Trojan horse effect. In Holter, H. (ed.). Patriarchy in a Welfare Society, pp. 88-104. Universitetsforlaget, Oslo. ISBN 82-00-07058-1.

Stoller, R. J. 1968. Sex and Gender, 383 pp. Hogart Press, London.

Straka, J. S., Wisdom, H. W. \& Moak, J. E. 1984. Size of the forest holding and investment behaviour of nonindustrial private owners. J. For. 82: 495-496.

Strupstad, L. M. 1990. Kvinner som skogeier. Analyse av en spørreksjemaundersøkelse. Telemark Research Foundation, Bö, Norway. Arbeidsrapport nr. 15/90, 109 pp. (In Norwegian.)

Strupstad, L. M. 1993. Den tause skogeier. In Brandt, B. \& Verstad, B. (eds). Kvinneliv i landbruket, pp. 23-52. Landbruksförlaget, Oslo. ISBN 82-529-1614-7. (In Norwegian.)

Thomson, R. P. \& Jones, G. J. 1981. Classifying nonindustrial private forest land by tract size. J. For. 79: $288-$ 289.

Törnqvist, T. 1995. Inheritors of the woodlands. Dept. of Forest-Industry-Market-Studies. Dissertation, Swedish University of Agricultural Sciences, Uppsala. Report No. 41, 442 pp. ISSN 0284-379X. (In Swedish with English summary.)

Whatmore, S. 1991. Life cycle or patriarchy? Gender division in family farming. J. Rural Stud. 7: 71-76. 